\title{
Recurrent differentiated thyroid cancer: to cut or burn
}

\author{
Roberto Cirocchi ${ }^{1 *}$, Stefano Trastulli ${ }^{1}$, Alessandro Sanguinetti ${ }^{2}$, Lorenzo Cattorini ${ }^{1}$, Piero Covarelli ${ }^{1}$, \\ Domenico Giannotti ${ }^{3}$, Giorgio Di Rocco ${ }^{3}$, Fabio Rondelli ${ }^{2}$, Francesco Barberini ${ }^{1}$, Carlo Boselli ${ }^{1}$, Alberto Santoro ${ }^{3}$, \\ Nino Gullà', Adriano Redler ${ }^{3}$ and Nicola Avenia ${ }^{2}$
}

The term "relapse carcinoma" is used improperly to indicate either a local or loco-regional relapse or a systematic metastatsis [1]. Local relapse (LR) after thyroidectomy for cancer is "the repetition of the neoplastic lesion in proximity of the previous intervention of excision" [2]. According to Duren [3] relapses of thyroidal carcinoma need to be classified as: local (LR): that may present itself in the residual thyroid lobe or in the thyroid bed where surgery was performed; loco-regional (RLR): that may present in the cervical lymph nodes of the central compartment or lateral-cervical nodes; and metastasis in distance (MD). The MD are frequently synchronous with LR or RLR; they have haematogenous genesis and concern most frequently the lungs and skeleton.

There is controversy over how to catergorize the relapse in the thyroidal bed with infiltrations of neighbouring organs (periodontal structures - muscles, thyroidal cartilage, cricoid, laryngeal nerves, etc. and the neighbouring organs - oesophagus, trachea, larynx). As per the classification proposed by Duren [3] these should be considered as LR, whereas according to Mozzillo and Pezzullo [1] they are categorised as RLR.

The RLR at the level of the cervical lymphnodal stations represents an ulterior problem: are these true relapses, residual cancer, or recurrence in progression? Caracò [4], in his report to the ninety-fourth Congress of the Italian Society of Surgery, specified that local recurrences are only those recurrences that are characterized by the appearance of neoplastic tissue in the thyroidal lodge, in the residual parenchyma, and in the adjacent structures, excluding the lymph nodes $[5,6]$.

In nearly $53 \%$ of cases the relapse is reported in RLR, in $28 \%$ in $\mathrm{LR}$, and in $13 \%$ the MD is present of these $6 \%$

\footnotetext{
* Correspondence: cirocchiroberto@yahoo.it

'General and Emergency Surgical Unit. Department of Surgical Sciences,

Radiology and Dentistry. University of Perugia, Perugia, Italy

Full list of author information is available at the end of the article
}

of cases have mixed relapses [7]; the prognosis of LR is however, better than that of the others [8]. The differentiated tumors of the thyroid are slow growing and due to this rarely reach notable dimensions or result in metastasis in lymph and/or haematic systems [2]. Only $10 \%$ of patients die from differentiated thyroid cancer [9].

Most of the local relapses occur within the first five years of the excision of the primary cancer [5,6,10-12], however, the recurrence can occur as late as 20 years after the initial diagnosis and treatment [13]. An accurate evaluation of incidence of LR is possible solely with a considerable number of treated patients and lengthy follow-up that is not available at most centres and hence this kind of information can be obtained from the date from centres that have high volume of thyroid carcinoma and good follow-up like Mayo Clinic or Lahey Clinic $[5,6,13]$ or through observational studies at several other medical centres [14].

Currently relapses represent a rare event in patients who undergo removal of thyroidal carcinoma (3-13\%) [5,6,10-12,15-17].

This is due to the ever increasing frequency of total thyroidectomy for management of cancer [18]. The complete excision of the thyroidal parenchyma prevents local recurrence. Giovanni Razzaboni in "Treatise on Prognostic Surgery" (1938) stated that "The most rational operating method, so long as not free from grave consequences of another kind, remains the total extra-capsular thyroidectomy, so as is used, when possible, for the surgical removal of whatever other tumour" [19]. he further emphasized in his work published after his death in 1956 entitled "Treatise on Clinical Therapeutic Surgery" that "Only an removal of this capacity justifies, in the face of a proven malignant tumour, surgical intervention, any other incomplete or partial demolition does nothing but accelerate the ready reoccurrences, even in a very short time" [20]. 
The causes and modalities of onset of local relapse are multiple. There exist a series of risk factors of local relapse that correlate to the specific neoplastic illness, of these the surgical treatment used, and use of adjuvant therapies are most important.

Patients affected with thyroidal carcinoma are subdivided into risk classes on the basis of the classification systems AGES (Age, Grading, Extrathyroidal extension and tumour size) (1987), AMES (Age, distant Metastasis, Extra thyroidal extension and tumour Size) (1988) and MACIS (distant Metastasis, Age, Completeness of resection, Invasion local, tumour Size) (1993) [21]. As per these classifications low risk (mortality rate within 10 years of 1-2\%)categories consists of men $<41$ years and women $<51$ years, with well differentiated tumor and tumors that are confined to the gland with absence of regional or distant metastasis, or older patients without extrathyroidal localization, either out of the thyroidal capsule or at distance or without extrathyroidal localization or out of the thyroidal capsule and patients with a tumor $<4 \mathrm{~cm}$ of maximum diameter. high risk on the other hand (mortality rate within 10 years of 50-75\%)are classified as all patients that do not fall into the previous category.

The most important risk factor in the onset of a local relapse is the stage of the previous tumor, particularly the local extension of the cancer and the involvement of the lymphnodes. The diameter of the neoplasia with significant risk of relapse varies from $<1.5 \mathrm{~cm}$ (Schroder et al.: $13 / 50$ relapses in tumors of higher diameter vs 4/55 in patients with smaller tumor) Grant et al.reported 5\% of relapses within 20 years for tumours smaller then 4 $\mathrm{cm}$ vs $15 \%$ for larger tumours $[5,6]$.

The spread of the cancer beyond the thyroidal capsule is another important risk factor. In Mayo Clinic study $5 \%$ of patients with intracapsular cancer relapsed within 20 years against $15 \%$ relapse in patients with extracapsular cancer. In the Lahey Clinic study relapse rates were higher at 52\% (17/33) [13,22].

The presence of lymph node metastasis and follicular carcinoma (7.3\% in papillary tumours vs $29.3 \%$ in follicular tumours in SICO trial) [14] are associated with an increased risk of local relapse. Moreover the age of the patient is an important variable with patietns over 45 years having higher mortality rates compared to younger patients. On the other hand, multifocality does not appear to be a significant risk factor in the development of local recurrence in patients who undergo total thyroidectomy (TT) or near total thyroidectomy (NTT) [23].

When LR appear they are associated with a poor prognosis and around $33-50 \%$ of these patients will die due to the resurgence of the illness [1]. With local relapse in the residual thyroidal tissue the outcome is less grave, compared to that involving the neighboring structures
[4]. Earlier relapses have been found to have poor prognosis compared to late relapses $(52.5 \%$ vs $85 \%$ [24].

In the past, at the 3-6 month the follow-up was conducted with a total body scan using a diagnostic dose of radio-iodine, TSH levels, thyroglobulin levels and antityreoglobulin antibodies. Currently, at the 3-6 month follow up is conducted with ultrasound of the neck and thyroglobulin measurements. The total body scan is no longer performed as routine as it is unable to diagnose the residual diseaseand provides no additonal information that is already provided by the levels of tyroglobulin after stimulation. The antityroglobulin antibodies estimation have false positive rate of $6 \%$ and false negative rate $1 \%[25]$.

Even at successive 6-12 month follow-up, only ultrasound and level of tyreoglbulin after stimulation with recombinant TSH is recomended. In the absence of suspected recurrence further ultrasound and biochemical check-up are conducted at 6 monthly or yearly intervals depending on the risk categories. In case of suspected local recurrence further verifications with imaging (computed tomography - CT- PET/CT, and/or total body scan) is recomended [26].

In the location of relapse tumours of the thyroid the sensitivity of TC ranges from 25 to $86 \%$ [25]. The magnetic resonance imaging (MRI) is particularly useful in differentiating the neoplatic tissues from the postoperative scar tissue [25]. The sensitivity of PET in the diagnosis of thyroidal carcinoma varies from 50 to $94 \%$; it is thus very useful in relapse cancers that do not take up $\mathrm{I}^{131}$. The accuracy of PET in anatomical locations is now increased with the use of PET-CT [25], which demonstrates a sensitivity of $80.7 \%$ and a specificity of $88.9 \%$ [27]. When the local recurrence or metastasis is suspected an ultrasound guided needle biopsy can be taken [1].

Currently the gold standard treatment for local relapse of thyroidal cancer is the radiometabolic treament with $\mathrm{I}^{131}$. The possible cures that surgery may offers in local recurrence is limited to selected cases [7]. Hence, surgical excision is advised only in cases of relapses that were not or cannot be completely treated solely with the radiometabolic treatment of $\mathrm{I}^{131}$.

In absence of early detection of relapse the resectibility rates are poor [28], and surgical intervention is marred by higher complecations [29,30].

The results of surgery seem to be better with local recurrences without involvement of the contiguous tissues; that constitute the minority of cases [4]. The use of intraoperative ultrasound helps in identification of the location of recurrent tumor and thus reduces the extent of the cervical dissection; this results in less postoperative complications. In patients who undergo removal of the recurrence associated with cervical 
dissection the prognosis is better with respect to patients in which a cervical dissection is not conducted $(\mathrm{P}=0.0169)[31]$.

The results are not always disappointing; in fact Henri Redon in his monograph "Indications chirurgicales dans le traitements des cancers/Surgical Guidelines in the Treatment of Cancers" (1962) wrote: "The question of relapse. It must be re-operated and can give significant results" [32].

The ERT (external radiotherapy) is reserved for patients with inoperable relapse or tumors where $\mathrm{I}^{131}$ is assumed to be ineffective [33].

Considering all the above facts and poor response of tumors to radio iodine and external therapy the multi organ resection may be considered in this select group of patients It could be a palliative resection in cases where there is a invasion of the larynx, trachea, or both organs. The infiltration of the larynx is often associated with recurring paralysis for the contemporaneous interest of a lower laryngeal nerve [34].

\section{Conclusions}

The survival of patients with local recurrence of disease in thyroid bed is better compated to those with loco-regional or metastatic disease. Ablation of the tumor by radio-iodine appears to be a better alternative however in select cases surgical resection can be considered.

\section{Author details \\ 'General and Emergency Surgical Unit. Department of Surgical Sciences, Radiology and Dentistry. University of Perugia, Perugia, Italy. ${ }^{2}$ Endocrine Surgical Unit. Department of Surgical Sciences, Radiology and Dentistry. University of Perugia, Perugia, Italy. ${ }^{3}$ Department of Surgical Sciences. Sapienza University of Rome, Rome, Italy.}

\section{Authors' contributions}

CR drafted the article. TS drafted the article. SA drafted. the article. CP cooperated in writing the article and translated it into English. VN made the tables. $\mathrm{CL}$ searched $>$ for the references and formatted the article. DG searched for the references and formatted the article. DRG collected patients' data. RF chose the most useful and interesting articles in literature about the field. CB searched for the references. SA searched for the references and collected the patients' consent. RA supervised the article production. NA allowed the collection of the patients' data and supervised the whole work making. All authors read and approved the final manuscript

\section{Competing interests}

The authors declare that they have no competing interests.

Received: 6 December 2010 Accepted: 12 August 2011 Published: 12 August 2011

\section{References}

1. Mozzillo N, Pezzullo L: Il carcinoma recidivo. In La patologia chirurgica della tiroide e delle paratiroidi. Edited by: Rosato L. GS Editrice, Santhià; 2000:194-197.

2. Fattovich G, Franceschini F, d'Atri C, Salatino G, Scandroglio I: La recidiva locoegionale nelle neoplasie della tiroide. Bollettino della Società Italiana di Chirurgia 1993, 14:207-214.
3. Duren E, Duren M: Recurrent thyroid cancer. In Textbook of endocrine surgery. Edited by: Clark OH, Duh QY. WB Saunders Company, Philadelphia; 1997:141-146

4. Caracò A, Santini L, Pezzullo L, Guerriero O: La recidiva nei cancri differenziati della tiroide. Archivio ed Atti Società Italiana di Chirurgia. Roma 1992, 2:29-33.

5. Grant CS, Hay D: Local recurrence of papillary thyroid carcinoma after unilateral or bilateral thyroidectomy. Wien Klin Wochenschr 1988, 100:342-6.

6. Grant CS, Hay ID, Gough IR, Bergstralh EJ, Goellner JR, McConaheu WM: Local recurrence in papillary thyroid carcinoma: is extent of surgical resection is important? Surgery 1988, 104:954-962.

7. Coburn M, Teates D, Wanebo HJ: Recurrent thyroid cancer. Role of surgery versus radioactive iodine $\left({ }^{131}\right)$. Ann Surg 1994, 219:587-93.

8. Waseem Z, Palme CE, Walfish P, Freeman JL: Prognostic implications of site of recurrence in patients with recurrent well-differentiated thyroid cancer. J Otolaryngol 2004, 33:339-44.

9. Hundahl SA, Fleming ID, Fremgen AM, Menck HR: A National Cancer Data Base report on 53,856 cases of thyroid carcinoma treated in the U.S., 1985-1995. Cancer 1998, 83:2638-2648.

10. Tollefsen HR, Decosse JJ: Papillary carcinoma of the thyroid. recurrence in the thyroid gland after initial surgical treatment. Am J Surg 1963, 106:728-34.

11. Starnes HF, Brooks DC, Pinkus GS, Brooks JR: Surgery for thyroid carcinoma. Cancer 1985, 55:1376-81.

12. Mueller-Gaertner HW, Brzac HT, Rehpenning W: Prognostic indices for tumor relapse and tumor mortality in follicular thyroid carcinoma. Cancer 1991, 67:1903-11.

13. Cady B, Rossi R: An expanded view of risk group definition in differentiated thyroid carcinoma. Surgery 1988, 104:947-953.

14. Antonaci A, Amanti C, Consoli C, Manzini A, Ficuccilli F, Tagliaferri M, Quartarone G, Oricchio U, Di Paola M: La ripresa di malattia nell'ambito della Ricerca Multicentrica SICO sul trattamento chirurgico del carcinoma della tiroide. In Atti XVII Congr Naz SICO. Volume I. Napoli 19-21 settembre; 1992:287-292.

15. Rossi RL, Nieroda C, Cady B, Wool MS: Malignancies of the thyroid gland. The Lahey Clinic experience. Surg Clin North Am 1985, 65:211-30.

16. Schröder S, Dralle H, Rehpenning W, Böcker W: Prognostic criteria of papillary thyroid cancer. Morphologic clinical analysis of 202 cases of tumor. Langenbecks Arch Chir 1987, 371:263-80.

17. Hamming JF, Van de Velde CJ, Goslings BM, Schelfhout LJ, Fleuren GJ, Hermans J, Zwaveling A: Prognosis and morbidity after total thyroidectomy for papillary, follicular and medullary thyroid cancer. Eur $J$ Cancer Clin Oncol 1989, 25:1317-23.

18. Brunicardi FC, Andersen DK, Billiar TR, Dunn DL, Hunter JG, Matthews JB, Pollock RE: Thyroid, Parathyroid, and Adrenal. Schwartz's Principles of Surgery, 9e The McGraw-Hill Companies; 2010.

19. Razzaboni G: Tiroide, paratiroide e timo. In Trattato di prognostica chirurgica: prognosi clinica e prognosi operativa. Edited by: Razzaboni G. Cappelli editore, Bologna; 1938:796-832.

20. Razzaboni G: Tumori della tiroide. In Trattato di clinica terapeutica chirurgica. Edited by: Razzaboni G. Cappelli editore, Bologna; 1956:1152-1157.

21. Miccoli P, Materazzi G, Ambrosini CE, Frustaci G: Carcinoma papillare. In Trattato italiano di endocrino chirurgia. Volume 1. Edited by: Rosato L. GS Editrice, Santhià; 2008:185-187.

22. Cady B, Meissner WA, Sala LE: Thyroid cancer for forty-one years. N Engl J Med 1978, 299:901

23. Ross DS, Litofsky D, Ain KB, Bigos T, Brierley JD, Cooper DS, Haugen BR, Jonklaas J, Ladenson PW, Magner J, Robbins J, Skarulis MC, Steward DL, Maxon HR, Sherman SI: Recurrence after treatment of micropapillary thyroid cancer. Thyroid 2009, 19:1043-8.

24. Lin JD, Hsueh C, Chao TC: Early recurrence of papillary and follicular thyroid carcinoma predicts a worse outcome. Thyroid 2009, 19:1053-9.

25. Ambrosi A, Fersini A, Tartaglia N, Neri V: Carcinoma recidivo. In Trattato italiano di endocrino chirurgia. Volume 1. Edited by: Rosato L. GS Editrice, Santhià; 2008:262-265.

26. Torlonato M, Attard M, Durante C, Filetti S: Follow-up e terapia postchirurgica dei carcinomi differenziati della tiroide. In Trattato italiano di endocrino chirurgia. Volume 1. Edited by: Rosato L. GS Editrice, Santhià; 2008:279-282. 
27. Razfar A, Branstetter BF, Christopoulos A, Lebeau SO, Hodak SP, Heron DE, Escott EJ, Ferris RL: Clinical usefulness of positron emission tomographycomputed tomography in recurrent thyroid carcinoma. Arch Otolaryngol Head Neck Surg 2010, 136:120-5.

28. Mattioli FP, Torre GC, Borgonovo G, De Negri A, Ansaldo GL, Amato A, Arezzo A: La ripresa di malattia nel carcinoma della tiroide. In Atti XVII Congr Naz SICO. Volume I. Napoli 19-21 settenbre; 1992:299-305.

29. Ruggiero FP, Fedok FG: Outcomes in reoperative thyroid cancer. Otolaryngol Clin North Am 2008, 41:1261-8

30. Shaha AR: Revision thyroid surgery - technical considerations. Otolaryngol Clin North Am 2008, 41:1169-83.

31. Uruno T, Miyauchi A, Shimizu K, Nakano K, Takamura Y, Ito Y, Miya A, Kobayashi K, Yokozawa T, Matsuzuka F, Kuma K: Prognosis After Reoperation for Local Recurrence of Papillary Thyroid Carcinoma. Surg Today 2004, 34:891-895.

32. Redon H: Cancer du corps thyroide. In Indications chirurgicales dans le traitement des cancers. Edited by: Redon H. Masson 1962:115-125.

33. Vianello F, Mazzarotto R: Radioterapia: aspetti clinici. In Trattato italiano di endocrino chirurgia. Volume 1. Edited by: Rosato L. GS Editrice, Santhià; 2008:283-286.

34. Puma F, Ragusa M, Avenia N: Infiltrazione laringea, tracheale ed esofagea. In Trattato italiano di endocrino chirurgia. Volume 1. Edited by: Rosato L. GS Editrice, Santhià; 2008:257-261.

doi:10.1186/1477-7819-9-89

Cite this article as: Cirocchi et al.: Recurrent differentiated thyroid cancer: to cut or burn. World Journal of Surgical Oncology 2011 9:89.

\section{Submit your next manuscript to BioMed Central} and take full advantage of:

- Convenient online submission

- Thorough peer review

- No space constraints or color figure charges

- Immediate publication on acceptance

- Inclusion in PubMed, CAS, Scopus and Google Scholar

- Research which is freely available for redistribution

Submit your manuscript at www.biomedcentral.com/submit
C Biomed Central 